\title{
COMPARISON THE VALUE OF BTA SPUTUM BETWEEN PULMONARY TUBERCULOSIS PATIENTS WITH DIABETES MELLITUS AND PULMONARY TUBERCULOSIS PATIENTS NON- DIABETES MELLITUS.
}

\author{
Bagas Setiawan Ihsan Zaini*1 ${ }^{*}$, Adyan Donastin ${ }^{2}$, Lea Maera Shanty ${ }^{3}$, Hotimah Masdan Salim ${ }^{4}$ \\ ${ }^{1}$ Faculty of Medicine, University of Nahdlatul Ulama Surabaya \\ ${ }^{2}$ Department Respiratory and Internal Medicine in Faculty of Medicine, University of Nahdlatul \\ Ulama Surabaya \\ ${ }^{3}$ Department of Internal Medicine, Faculty of Medicine, University of Nahdlatul Ulama Surabaya \\ 4 Department Medical Biochemistry, Faculty of Medicine, University of Nahdlatul Ulama \\ Surabaya \\ *Corresponding Author: bagassetiawan.bs@gmail.com
}

\begin{abstract}
ABSTRAK
Background \& Aims: Tuberculosis (TB) is a health problem. Based on the WHO report in 2016, Indonesia is a developing country with the second largest TB case. One risk factor for pulmonary tuberculosis is having a history of diabetes mellitus disease. The aim of this research is to examine the differences the value of BTA sputum between pulmonary TB patients with diabetes mellitus and pulmonary TB patients non-diabetes mellitus.

Methods: This research is descriptive analytic with comparative study. This study uses secondary data in Islamic Jemursari Surabaya Hospital period January - December 2017. The results will be processed using descriptive analysis and Mann-Whitney test with SPSS 25.00 for windows.

Results: This research obtained 68 samples consisting of 34 the pulmonary TB non-diabetes mellitus and 34 pulmonary TB with diabetes mellitus. In pulmonary TB patients non-diabetes mellitus most have negative BTA sputum values, while pulmonary TB with diabetes mellitus is positive $(+1)$, so there are differences in the value of BTA sputum with a significance value 0.001 $(<0.05)$.

Conclusion: There is a difference in the value of BTA sputum between pulmonary TB patients with diabetes mellitus and pulmonary TB patients non-diabetes mellitus. It caused in patients with diabetes mellitus have immunological abnormalities, especially IFN- $\gamma$ and pulmonary physiological disorder.
\end{abstract}

Key word: Pulmonary Tuberculosis, Diabetes Mellitus, BTA.

List of Abbreviations: TB - Tuberculosis, DM - Diabetes Mellitus, BTA - Bacilli Resistant Acid, WHO - World Health Organization, IDF - International Diabetes Federation

\section{Introduction}

Tuberculosis (TB) is an infectious disease caused by mycobacterium tuberculosis which mainly attacks the pulmonary parenchyma (Amin and Bahar, 2014). Tuberculosis is still a major problem in global health and one of the most common causes of death in the world. Based on the global tuberculosis report in 2016 there were around 10.4 million people suffering from TB disease 1.3 million of them died, and 0.8 million of them had diabetes. Indonesia is the second endemic country of TB (WHO, 2017). Some risk factors for TB are immunocompromised factors, that is diabetes mellitus (DM). The condition of DM can increase five times the risk of being infected with TB (Widyasari et al., 2012).

Diabetes Mellitus (DM) also a global health problem, recorded in 2017 diabetes mellitus in the world reached 425 million and it is estimated that in 2045 there will be an increase of 629 million. Indonesia occupies number 6 as the most country with 10.3 million people with diabetics (IDF, 2017). The increasing number of DM patients, so it will increase role of DM in the incidence of pulmonary TB, especially in TB endemic countries such as Indonesia. 
Diagnosing pulmonary TB beside seeing the clinical manifestations in the form of cardinal sign, other examination need to be carried out such as examination of microscopic BTA sputum or x-rays (PDPI, 2011). Source of transmission pulmonary TB is pulmonary TB patients who have positive (+) smear results that are transmitted in droplet infection. A person who diagnosed with TB with a positive (+) smear status, can transmit approximately 10-15 people each year (Adiatama, 2013).

From above, researchers are interested in conducting a study on "Comparison of the Value of Microscopic BTA Sputum Between pulmonary TB patients without DM and pulmonary TB patients with DM at Islamic Jemursari Surabaya Hospital in the January-December 2017".

\section{Methods}

\section{Study Design and Patient Population}

This study is a retrospective case control study conducted at Department of Pulmonary of Islamic Jemursari Hospital of Surabaya from January to December 2017. The population of this study were all tuberculosis patients with the criteria inclusion of this study is were pulmonary TB patients with or without diabetes mellitus, carry out bacteriological examination of BTA sputum at the beginning of the month (0), age $\geq 15$ years-old and outpatient. The sample of this research amounted to 68 taken by purposive sampling and consisting of 34 the pulmonary TB non-diabetes mellitus and 34 pulmonary TB with diabetes mellitus.

\section{Statistical Analysis}

We compared finding among TB patients with DM those without DM. Statistical analysis using SPSS version 25. Quantitative variables are reported as amounts (\%). The Mann-Whitney test was used to compare 2 groups of samples with ordinal scale variables. The significance level used is $95 \%$ with a significance value of $5 \%$. We assigned statistical significance as $P$ value $<0.05$.

\section{Results}

\section{Characteristics of Pulmonary tuberculosis}

The majority of pulmonary TB patients without DM and pulmonary $\mathrm{TB}$ patients with DM who were respondents in this study were mostly men $(58.8 \%$ and $70.6 \%)$ compared to woman $(42.2 \%$ and $29.4 \%$ ).

Pulmonary TB patients without DM who were respondents in this study mostly $(32.4 \%)$ were included in the 35-44 year age category. Then patients with pulmonary TB with DM who were respondents in this study mostly (41.2\%) were included in the 45-54 year age category. The overall descriptive characteristic of the study population is presented in Table 1.

Table 1: Characteristics of Pulmonary TB with DM and TB without DM

\begin{tabular}{lccccc}
\hline Variable & n & \multicolumn{2}{c}{$\begin{array}{c}\text { Pulmonary TB without } \\
\text { DM }\end{array}$} & \multicolumn{2}{c}{ Pulmonary TB with DM } \\
& & \multicolumn{2}{c}{$\mathbf{n}$} & $\mathbf{n}$ & $\%$ \\
\hline Sex & & & & & \\
Men & 44 & 20 & $58,8 \%$ & 24 & $70,6 \%$ \\
Woman & 24 & 14 & $41,2 \%$ & 10 & $29,4 \%$ \\
Age & 7 & 6 & $17,6 \%$ & 1 & $2,9 \%$ \\
15-24 years & 7 & 6 & $17,6 \%$ & 1 & $2,9 \%$ \\
25-34 years & 15 & 11 & $32,4 \%$ & 4 & $11,8 \%$ \\
35-44 years & 20 & 6 & $17,6 \%$ & 14 & $41,2 \%$ \\
45-54 years & 14 & 3 & $8,9 \%$ & 11 & $32,4 \%$ \\
55-64 years & 5 & 2 & $5,9 \%$ & 3 & $8,8 \%$ \\
$>$ 65 years & & & & & \\
\hline
\end{tabular}

The majority of pulmonary TB patients without DM who were respondents in this study $(58.8 \%)$ had microscopic BTA sputum values that were in the negative category, while pulmonary TB patients with DM had positive microscopic BTA sputum values $(79,4 \%)$ and the most $(35.3 \%)$ had microscopic BTA sputum values in the positive $1(+1)$ category. The overall value of the study population is presented in Table 2 . 


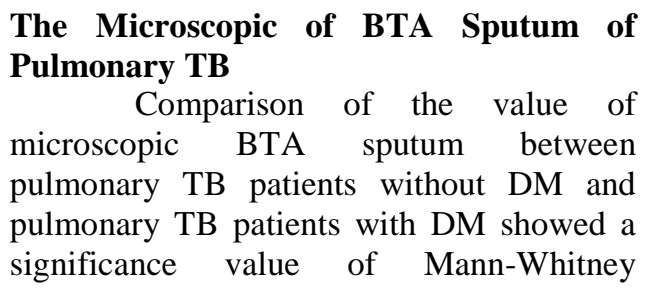

obtained at $0.001(<0.05)$, which means that there were significant differences in the value of microscopic BTA sputum between the two types of patients compared. This is confirmed by the different categories of assessment of microscopic BTA sputum.

Table 2: The Value of Microscopic BTA Sputum of Pulmonary TB with DM and TB without DM

\begin{tabular}{lccccc}
\hline $\begin{array}{c}\text { The Value of } \\
\text { Microscopic BTA } \\
\text { Sputum }\end{array}$ & $\mathbf{n}$ & $\begin{array}{c}\text { Pulmonary TB without DM } \\
\text { \% }\end{array}$ & \multicolumn{2}{c}{$\begin{array}{c}\text { Pulmonary TB with DM } \\
\text { n }\end{array}$} & \% \\
\hline Negative & 27 & 20 & $58,8 \%$ & 7 & $20,6 \%$ \\
Positive 1 (+1) & 21 & 9 & $26,5 \%$ & 12 & $35,3 \%$ \\
Positive 2 (+2) & 7 & 2 & $5,9 \%$ & 5 & $14,7 \%$ \\
Positive 3 (+3) & 13 & 3 & $8,8 \%$ & 10 & $29,4 \%$ \\
\hline
\end{tabular}

Table 3: The Value of Microscopic BTA Sputum of Pulmonary TB with DM and TB without $\mathrm{DM}$

\begin{tabular}{lcc}
\hline Parameter & $\begin{array}{c}\text { The Value of Microscopic BTA } \\
\text { Sputum of Pulmonary TB without } \\
\text { DM }\end{array}$ & $\begin{array}{c}\text { The Value of Microscopic BTA } \\
\text { Sputum of Pulmonary TB with } \\
\text { DM }\end{array}$ \\
\hline Modus & Negative & Positive 1 \\
Sample & 34 & 34
\end{tabular}

Significance Mann-Whitney test $=0,001(<0,05)$

\section{Discussion}

Characteristics of patients according to their sex in table 1, pulmonary TB patients without DM and pulmonary TB patients with DM found that the prevalence of men was more than female. This is appropriate with the results of a study conducted by Harso et al (2017) which also shows a similar thing.

According to WHO (2017), globally men are twice as likely to be infected with TB than women. Men with DM or not tend to be more susceptible to Mycobacterium tuberculosis infection than women, but the reason is not yet clear, possibly because of smoking habits (Wijayanto et al., 2015). Nicotine contained in cigarette smoke can disrupt the respiratory immunity system by damaging mucociliary and reduce its, especially inhibiting TNF- $\gamma$ production in pulmonary alveolar macrophages, so smokers are more susceptible to infection with M. tuberculosis (Kolappan et al., 2007). In addition to smoking habits, men tend to pay less attention to their health and daily lifestyle, such as frequent drinking alcohol or more outside the home at night. This will increase the risk factors for exposure to Mycobacterium tuberculosis infection and will have an impact on the low immune system (Susilayanti and Medison, 2014). Characteristics of patients according to age in table 1, pulmonary TB patients with DM mostly were $45-54$ years $(41.2 \%)$. This is appropriate with the results of previous studies conducted by Harso et al (2017) which showed the same results.

Akaputra et al (2011) said that the risk of developing diabetes mellitus is $>40$ years old. With the increasing age of a person with DM the possibility of infection is more frequent, especially in patients with uncontrolled diabetes. This is because in the age group above 40 years, a person tends to be less active in activities so that muscle mass will decrease and body weight will increase. In addition, the longer a person suffers from diabetes mellitus will result in progressive beta cell shrinkage which eventually occurs beta cell damage in old age (D'adamo, 2008). While in pulmonary TB patients without DM have different results, the age group <45 years has a higher percentage $(67.6 \%)$, where the highest age group is 35-44 years old $(32.4 \%)$. This is slightly different from the results of a study conducted by Harso et al (2017) which showed that the highest age 
group was 25-34. Dhamagaye (2008) and Rao et al (2014) say that in the productive age group there is a high association with activity, social interaction, mobility, and work. So that the possibility of being exposed, infected and contracting pulmonary TB germs is greater. Besides that, the smoking habit that is increasing in the young age group is also one of the risk factors for many cases of TB.

Pulmonary TB patients without DM had negative category of BTA sputum $(58.8 \%)$, this is appropriate with previous studies conducted by Djakaria et al (2017) which showed that of 74 respondents, 57 respondents has a negative value of BTA sputum (77.03\%). Girsang et al (2006) also showed that examination of BTA sputum on 160 slides using the IUATLD scale conducted by microbiology doctors found 96 $(60 \%)$ included in the negative category. While pulmonary TB patients with DM having a positive category of BTA sputum (79.4\%), this is appropriate with previous studies conducted by Nasution (2007) showing $65.9 \%$ of DM patients with pulmonary $\mathrm{TB}$ in RSUP $\mathrm{H}$ Adam Malik Medan on bacteriological examination had positive BTA sputum values. Zalitha (2011) also said that of 149 sufferers suffering from pulmonary TB with positive smear who had a comorbid illness, Diabetes Mellitus was $77.2 \%$.

Bacteriological examination with microscopic BTA sputum is a major diagnostic checkup in developing countries, because this examination is the easiest, cheapest, efficient, and fast (WHO), 2017). The negative / positive value of BTA sputum can reflect the large number of bacteria, the extent of lung lesions in some pulmonary TB patients have the potential for transmitting germs to others (Rajpal et al, 2002). According to Mulyadi and Mudatsir (2011) there are several factors that can influence the results of BTA sputum examination, such as inadequate methods of examination, too little germs due to inadequate sputum extraction, and the effect of anti-tuberculosis drug treatment (OAT). Pranowo (2006) also reported that an effective coughing method for sputum removal could affect the results of microscopic BTA sputum examination in pulmonary TB patients.

According to Widyasari et al (2012) someone with a history of diabetes mellitus (DM) has a 5 times greater risk of being infected with tuberculosis compared to people who do not have a history of DM disease. Wang et al (2013) also showed that pulmonary TB patients with DM had a BTA sputum 2.5 more positive than non-DM pulmonary patients.

The cause of an increase in the incidence of pulmonary TB in patients with DM occurs due to defects or decreased function of immune cells and host defense mechanisms. Guptan and Shah (2000) also said that in addition to the presence of immunological disorders in the form of decreases in Th- 1 , TNF- $\alpha$, and IFN- $\gamma$ responses, there were also some reduction in pulmonary physiological functions, such as: reduced bronchial reactivity, decreased recoil and lung volume elasticity, reduced diffusion capacity, presence of mucus that clogs the respiratory tract and reduced ventilation response. IFN- $\gamma$ is a lymphokine which has an important role to increase the progression of $\mathrm{T}$ lymphocytes to the performance of alveolar macrophages (Abbas et al, 2010). This can be seen in the research conducted by Wang et al (2013) and Alisjahbana et al (2006)Saying that the proportion of mature alveolar macrophages is lower in pulmonary TB patients with DM compared to pulmonary TB patients without DM, which causes the process of phagocytosis of TB germs carried out by less activated alveolar macrophages or decreased and the ability of monocytic chemotaxis also disrupted. It is estimated that it can play a role in the large number of bacteria in sputum of TB patients with DM (Alisjahbana et al., 2006; Cahyadi A, 2011).

\section{Conclusion}

In conclusion, our results demonstrated that a difference in the value of BTA sputum between pulmonary TB patients with diabetes mellitus and non-diabetes mellitus may cause of the immunological abnormalities mechanism, especially IFN- $\gamma$ and pulmonary physiological disorder. Further studies are needed to elucidate those mechanism.

Conflict of Interest: The authors declare no conflict of interest in the conduct and reporting of this study.

Acknowledgements: We sincerely thank and appreciate to Institute for Research and Community Service University of Nahdlatul Ulama Surabaya 


\section{Reference}

1. Abbas, A.K., Lichtman, A.H and Pillai, S. (2010). Selular and molecular immunology. 6th edn. Philadelphia: John E.Kennedy Blvd Ste 1800.

2. Adiatama, T. (2013). Tuberkulosis diagnosis, terapi dan masalahnya. Jakata: Lab Mikrobiologi RSUP Persahabatan.

3. Akaputra, R., Burhan, E and Nawas, A. (2011). Karakteristik dan evaluasi perjalanan penyakit multidrug resistant tuberculosis dengan diabetes mellitus dan non diabetes mellitus. $J$ Respir Indo. 33(2): 92-102.

4. Alisjahbana, B., van Crevel, R., Sahiratmadja, E., den Heijer, M., Maya, A., et al. (2006). Diabetes mellitus is strongly associated with tuberkulosis in indonesia. Int J Tuberc Lung Dis. 10(6):696-700.

5. Amin, Z and Bahar, A. (2014). Buku Ajar Ilmu Penyakit Dalam: Tuberkulosis paru. 6th edn. Jakata: Pusat Penerbitan Departemen Ilmu Penyakit Dalam Fakultas Kedokteran Universitas Indonesia.

6. Cahyadi A, V. (2011). Tuberkulosis Paru pada Pasien Diabetes Mellitus. J Indon Med Assoc. 61(4).

7. D'adamo, P. (2008). Diet Sehat Diabetes sesuai golongan darah. Yogyakarta: Delapratasa.

8. Dhamagaye, T. (2008). Tobacco smoking and pulmonary tuberculosis. J. Indian Med. Assoc. 106:216-219.

9. Djakaria, M. Y. I., Rares, F. E. S. and Porotu'o, J. (2017). Hasil Diagnostik Mycobacterium Tuberculosis pada Pasien dengan Batuk > 2 Minggu Menggunakan Pewarnaan ZiehlNeelsen Di Poliklinik Paru Rumkit Tingkat III Robert Wolter Mongisidi. Jurnal e-Biomedik (eBm). 5(2).

10. Girsang, M., Partakusuma, LG and Lesthiowati, D., E. (2006). Penilaian Mikroskopis Bakteri Tahan Asam (BTA) Menurut Skala International Union Association Lunag Tuberculosis Disease (IUALTD) di Instalasi Laboratorium Mikrobiologi RS Persahabatan Jakarta. Media Litbang Kesehatan. 16(3): 42-48.

11. Guptan, A and Shah, A. (2000). Tuberculosis and diabetes: An appraisal. Ind. J. Tub. 47: 3-6.

12. Harso, A.D., Syarif, A.K., Arlinda, D.,
Indah, R.M., Yulianto, A., Yudhistira, A and Karyana, M. (2017). Perbedaan Faktor Sosiodemografi dan Status Gizi Pasien Tuberkulosis dengan dan Tanpa Diabetes Berdasarkan Registri Tuberkulosis-Diabetes Melitus 2014. Media Litbangkes. 27(2): 65-70.

13. IDF. (2017). IDF Diabetes Atlas Eighth edition 2017. International Diabetes Federation.

14. Kolappan C, Gopi PG, S. and PR, N. (2007). Selected biological and behavioural risk factors associated with pulmonary tuberculosis. Intt $J$ Tuberc Lung Dis 11(9): 999-1003.

15. Mulyadi, Mudatsir, N. (2011). Hubungan Tingkat Kepositifan Pemeriksaan Basil Tahan Asam (BTA) dengan Gambaran Luas Lesi Radiologi Toraks pada Penderita Tuberkulosis Paru yang Dirawat di SMF Pulmonologi RSUDZA Banda Aceh. J Respir Indo. 31(3): 133-137.

16. Nasution, E. (2007). Profil penderita tuberkulosis paru dengan diabetes melitus dihubungkan dengan kadar gula darah puasa (tesis). Medan: Fakultas Kedokteran Universitas Sumatera Utara.

17. PDPI. (2011). Tuberkulosis: Pedoman diagnosis dan Penatalaksanaan di Indonesia revisi Pertama. Jakata: PDPI.

18. Pranowo, C. (2006). Efektifitas Batuk Efektif dalam Pengeluaran Sputum untuk Menentukan BTA pada Pasien TB Paru di Ruang Rawat Inap Rumah Sakit Mardi Rahayu Kudus.

19. Rajpal, S., Dhingra, VK and Aggarwal, J. (2002). Sputum Grading as Predictor of Treatment Outcome in Pulmonary Tuberculosis. Ind J Tub. 49: 139-141.

20. Rao, VG., Bhat, J., Yadav, R., Muniyandi, M., Bhondeley, MK., Sharada, MA., et al. (2014). Tobacco smoking: major risk factor for pulmonary tuberculosis-evidence from a cross-sectional study in central India. Trans. R. Soc. Trop. Med. Hyg. 108: 474-481.

21. Susilayanti, E. Y. and Medison, I. (2014). Artikel Penelitian Profil Penderita Penyakit Tuberkulosis Paru BTA Positif yang Ditemukan di BP4 Lubuk Alung periode Januari 2012 Desember 2012. Jurnal Kesehatan Andalas. 3(2):151-155. 
22. Wang Q, Ma A, Han X, et al (2013). Prevalence of type 2 diabetes among newly detected pulmonary tuberculosis patients in China: a community based cohort study. PLoS One. 8, p. e82660.

23. World Health Organization (WHO). (2017). Global Tuberculosis Report. Geneva: World Health Organization.

24. Widyasari, R.N., Wuryanto, M.A and Setyawan, H. (2012). Hubungan antara Jenis Kepribadian, Riwayat Diabetes Melitus dan Riwayat Paparan Merokok dengan Kejadian
TB Paru Dewasa di Wilayah Kecamatan Semarang Utara Tahun 2011. J Kesehat Masy. 1(2): 446-53.

25. Wijayanto, A., Burhan, E and Nawas, A., R. (2015). Faktor terjadinya tuberculosis paru pada pasien diabetes mellitus tipe 2. J Respir Indo. 35(1): $1-11$.

26. Zalitha, S. (2011). Profil penderita penyakit tuberkulosis paru di RSU Siti Hajar Medan (skripsi). Medan: Fakultas Kedokteran Universitas Sumatera Utara. 